\title{
Influence of Paclobutrazol and Ethephon on Vegetative Growth of Guava (Psidium guajava L.) Plants at Different Spacing
}

\author{
Jaswinder Singh BRAR \\ Regional Research Station (PAU) Bathinda-151001,Punjab, India; jsbrar74@rediffmail.com
}

\begin{abstract}
To ascertain the growth retarding potential of Paclobutrazol (PBZ) and Ethephon on guava plants at different spacing viz $6 \times 2 \mathrm{~m}, 6 \times 3$ $\mathrm{m}, 6 \times 4 \mathrm{~m}$ and $6 \times 5 \mathrm{~m}$; both were applied at $500 \mathrm{ppm}, 1000 \mathrm{ppm}$ as a foliar spray. Investigation revealed that all treatments influence the vegetative growth of plants compared to untreated plants at all spacing levels. However, paclobutrazol considerably restrict the overall vegetative growth of trees. Stock and scion girth was found to be increased with ethephon treatments. The tree height and E-W tree spread was found to increased with increasing plant density. Similarly, trunk girth in terms of stock and scion girth was also increased with increase in plant spacing. Although, the PBZ $500 \mathrm{ppm}$ markedly restrict the plant growth but it may be further investigated for managing the guava tree canopies under high density planting systems, taking the fruit quality and economic aspects into consideration.
\end{abstract}

Keywords: guava, spacing, paclobutrazol, ethephon, vegetative growth

\section{Introduction}

Guava (Psidium guajava L.) is very important tropical fruit crop grown throughout the tropical and sub-tropical areas. It is a hardy, prolific bearer and highly remunerative fruit crop and also can be grown satisfactorily even in adverse soil and climatic conditions. The area and production of guava is increasing worldwide, but there is no significant increase in productivity. Presently, the productivity of guava is smaller than productive potential primarily due to traditional system of wider planting and secondarily due to poor canopy management practices. Therefore, the main emphasis should be laid on management of tree canopy in such a way that leads to accommodation of higher number of plans to get higher production of good quality fruits per unit area.

In the absence of dwarfing rootstocks for guava, techniques that restrict the vegetative growth are important in management of tree canopy. As guava tree respond well to canopy modification with respect to vegetative and reproductive growth (Singh and Chanana, 2005), therefore, modification of canopy through pruning and use of certain growth regulators along with increasing the plant density may be steps to enhance the production efficiency.

Paclobutrazol and ethephon may be useful in high density planting as paclobutrazol helps in making the plants dwarf by producing a retarding effect on the growth of tree through inhibition of gibberellin biosynthesis, a key plant growth promoter. Similarly, ethephon acts as a ripening hormone and it enhances the ripening process along with its growth retardation effect. Ethephon at higher concentrations (500-3000 ppm) proved to be quite effective in reducing the plant height (Mohammed et al., 1984). Ear- lier, Singh (2006) and Singh and Bal (2006) also investigated the positive effect of PBZ application in restriction of vegetative growth of guava plants.

Keeping in view the above mentioned facts, the present research aimed to restrict the vegetative growth of guava 'Allahabad Safeda' in order to obtain a higher density orchard.

\section{Materials and methods}

The present investigations were carried out in the 'New Orchard, Department of Horticulture, Punjab Agricultural University, Ludhiana (India) during the years 2007 to 2009. The plants of guava 'Allahabad Safeda' raised on 'L-49' rootstock were planted in March, 2003 at different spacing viz. $6 \times 2 \mathrm{~m}, 6 \times 3 \mathrm{~m}, 6 \times 4 \mathrm{~m}$ and $6 \times 5 \mathrm{~m}$. Paclobutrazol (PBZ), [(2RS,3RS)-1-(4-chlorophenyl)-4,4-dimethyl-2-(1,2,4 triazol-1-yl)pentan-3-ol], a gibberellin-inhibitor and Ethephon [(2-chloroethyl) phosphonic acid], a ripening hormone and inhibitor of growth promoting factors; each was applied at 500 ppm, $1000 \mathrm{ppm}$ as a foliar spray in the month of March before the onset of flowering. The control plants were sprayed with water only.

The growth of the experimental trees was recorded in terms of stock girth, scion girth, tree height; tree spread (East-West and North-South directions) and tree canopy volume in both the years in the month of September. The stock girth was measured $5 \mathrm{~cm}$ below the graft union and the scion girth was measured $5 \mathrm{~cm}$ above the graft union with the help of measuring tape. Height and spread (E-W and N-S) of the trees was measured with the help of measuring pole. The plants in N-S direction was intermingled 
in $6 \times 2 \mathrm{~m}$ spacing level; therefore the spread was limited to $3.00 \mathrm{~m}$ under all treatment levels by removing the extra shoots. The tree canopy was calculated by formula given by Roose et al. (1986) in $\mathrm{m}^{3}$.

$$
\boldsymbol{v}=\frac{4}{6} \Pi \boldsymbol{h} \boldsymbol{r}^{2}
$$

Where, $\mathrm{h}=$ height of tree $(\mathrm{m})$

$r=\frac{\text { Sum of } E-W \text { and } N-S \text { directions (in meters) }}{4}$

E-W=East-West, N-S=North-South

\section{Results and discussion}

\section{Stock girth}

Ethephon at both concentrations, influence the stock girth (Tab. 1) of guava plants. Significant higher stock girth was recorded in plants sprayed with ethephon 1000 ppm as compared to other treatments and untreated plants. This may be due to radial growth enhancing property of ethephon. However, the present investigations are not fully agree with the results of Singh (2006) in which non-significant difference of stem girths under all these treatments in guava 'Sardar' was observed.

The stock girth was found to be increased with increase in plant spacing. Maximum mean stock girth was recorded in plants at $6 \times 5 \mathrm{~m}$ spacing and least at closest spacing of $6 \times 2 \mathrm{~m}$ (Tab. 1). The increase in stock girth with plant spacing may be owing to reduced competition between the plants for obtaining moisture, nutrients and sunlight and other requirements and it is also justified by greater availability of photosynthates going in reserve tissues in plants at wider spacing. The results of present study are in line with those of Sidhu et al. (1992), who also obtained maximum tree girth in guava from widely spaced trees. Similar results have been obtained by Singh and Bal (2002), Bal and Dhaliwal (2003) in guava.

Maximum stock girth was obtained for $6 \times 4 \mathrm{~m}$ at 1000 ppm ethephon (Tab. 1). However, the minimum stock girth was recorded in $6 \times 4 \mathrm{~m}$ at $500 \mathrm{ppm}$ ethephon application.

Tab.1. Effect of growth regulators on stock girth $(\mathrm{cm})$ of guava 'Allahabad Safeda', planted in different spacing

\begin{tabular}{cccccc}
\hline Treatments & $6 \times 2 \mathrm{~m}$ & $6 \times 3 \mathrm{~m}$ & $6 \times 4 \mathrm{~m}$ & $6 \times 5 \mathrm{~m}$ & Mean \\
\hline PBZ 500 & 41.42 & 42.42 & 44.08 & 49.50 & 44.36 \\
PBZ 1000 & 43.75 & 40.50 & 45.33 & 46.58 & 44.04 \\
Ethephon 500 & 42.58 & 45.66 & 38.88 & 49.41 & 44.13 \\
Ethephon 1000 & 42.91 & 43.97 & 53.41 & 50.00 & 47.57 \\
Control & 40.16 & 43.50 & 43.75 & 47.50 & 43.73 \\
Mean & 42.16 & 43.21 & 45.09 & 48.60 & 44.77 \\
\hline
\end{tabular}

$\mathrm{CD}(p-0.05)$ Spacing (A):1.10 Treatments (B):1.23 A × B:2.46

\section{Scion girth}

Higher scion girth was recorded in plants treated with ethephon 1000 ppm application followed by PBZ 500 ppm treatment (Tab. 2). Untreated plants exhibited least scion girth. The scion girth was also affected significantly by various spacing. The mean maximum scion girth was noted in $6 \times 5 \mathrm{~m}$ which was significantly higher than other spacing levels and minimum mean scion girth was recorded in plants at $6 \times 2 \mathrm{~m}$ spacing. This may be due to more shading effect and reduced availability of carbohydrates at closer spacings. Singh and Bal (2002) and Bal and Dhaliwal (2003) also reported maximum scion girth in wider spacing. In similar observations Singh et al. (2007) also recorded increment in trunk circumference with increase in plant spacing.

Plants at $6 \times 4 \mathrm{~m}$ spacing treated with ethephon 1000 ppm exhibited highest scion girth (Tab. 2). The ethephon treatment may enhance the radial growth of stems due to which the scion girth may increase under higher dose of ethephon. The present results are in accordance with the observations of Singh (2006) who recorded higher scion girth of guava plants with ethephon and PBZ treatment.

Tab. 2. Effect of growth regulators on scion girth $(\mathrm{cm})$ of guava Allahabad Safeda, planted in different spacing

\begin{tabular}{cccccc}
\hline Treatments & $6 \times 2 \mathrm{~m}$ & $6 \times 3 \mathrm{~m}$ & $6 \times 4 \mathrm{~m}$ & $6 \times 5 \mathrm{~m}$ & Mean \\
\hline PBZ 500 & 38.91 & 40.25 & 41.76 & 45.36 & 41.57 \\
PBZ 1000 & 40.05 & 39.33 & 41.91 & 42.56 & 40.96 \\
Ethephon 500 & 40.48 & 41.33 & 36.83 & 44.58 & 40.81 \\
Ethephon 1000 & 40.03 & 40.41 & 46.91 & 45.78 & 43.28 \\
Control & 37.50 & 38.33 & 40.08 & 44.30 & 40.55 \\
Mean & 39.39 & 39.93 & 41.50 & 44.92 & 41.43 \\
\hline
\end{tabular}

$\mathrm{CD}(p-0.05)$ Spacing (A):1.18 Treatments (B):1.32 A $\times$ B: NS

\section{Tree height}

Growth regulators also have a significant impact on height of guava trees. Tree height in all the treated plants was decreased. PBZ $500 \mathrm{ppm}$ proved to be quite effective in limiting the plant height (Tab. 3). This reduction in tree height may be due to antagonistic effect of PBZ to gibberellins, which are primarily responsible for the inhibition of cell division and cell elongation in the sub-apical meristem of the trees, which is promoted by gibberellins and ethephon induced inhibition of growth promotion properties. Similar results were reported by Mohammed et al. (1984) that ethephon was quite effective in reducing the plant height in guava meadow orchard. Singh (2006) also observed the similar changes in tree heights with growth retardants.

The mean maximum tree height was recorded in closest $(6 \times 2 \mathrm{~m})$ spacing which was found decreased with increase in plant spacing. Minimum tree height was recorded 
112

Tab. 3. Effect of growth regulators on plant height $(\mathrm{m})$ of guava 'Allahabad Safeda', planted in different spacing

\begin{tabular}{cccccc}
\hline Treatments & $6 \times 2 \mathrm{~m}$ & $6 \times 3 \mathrm{~m}$ & $6 \times 4 \mathrm{~m}$ & $6 \times 5 \mathrm{~m}$ & Mean \\
\hline PBZ 500 & 3.91 & 3.65 & 3.23 & 3.17 & 3.49 \\
PBZ 1000 & 3.95 & 3.76 & 3.35 & 3.24 & 3.58 \\
Ethephon 500 & 4.00 & 3.79 & 3.80 & 3.39 & 3.75 \\
Ethephon 1000 & 3.68 & 3.47 & 3.53 & 3.46 & 3.54 \\
Control & 3.98 & 3.92 & 3.76 & 3.49 & 3.79 \\
Mean & 3.90 & 3.72 & 3.53 & 3.35 & 3.63 \\
\hline
\end{tabular}

CD (p-0.05) Spacing (A):0.054 Treatments (B): $0.060 \mathrm{~A} \times \mathrm{B}: 0.12$

in plants at widest $(6 \times 5 \mathrm{~m})$ spacing. It was observed that wider spacing tended to reduce the plant height because in wider spacing sufficient space is left for the spread of plants and moreover the greater competition for light may be the other factor. The results of tree height in 'Sardar' guava obtained by Yadav et al. (1981) are in consonance with the present investigations. Sidhu et al. (1992), Bal and Dhaliwal (2003), Singh et al. (2005) and Gaur et al. (2005) also recorded reduced tree height in guava plants in wider spacing.

Among all, maximum tree height $(4.00 \mathrm{~m})$ was recorded in $6 \times 2 \mathrm{~m}$ spacing, when plants were sprayed with ethephon $500 \mathrm{ppm}$ and control $(3.98 \mathrm{~m})$ plants. The minimum tree height was noted in $6 \times 5 \mathrm{~m}(3.17 \mathrm{~m})$ spacing, when the plants were sprayed with PBZ 500 ppm followed by $3.23 \mathrm{~m}$ at $6 \times 4 \mathrm{~m}$ spaced plants under same treatment.

\section{Tree spread}

The tree spread along East-West and North-South was influenced significantly with PBZ and ethephon treatments as well as plant spacing. All treatments restricted the plant spread. Maximum restriction was observed with PBZ $500 \mathrm{ppm}$ treatment in E-W (Tab. 4) direction and with ethephon $500 \mathrm{ppm}$ in N-S (Tab. 5) direction. Plant spread in E-W and N-S direction was noted maximum in control plants. Yadav et al. (1981) reported similar results in guava with regard to tree spread. The number of branches per tree decreased with increasing plant density. This reduction in tree spread under growth retardants may be due to antagonistic effect of paclobutrazol and ethephon. Recently, Reddy and Kurian (2008) also reported

Tab. 4. Effect of growth regulators on tree spread (E-W) (m) of guava 'Allahabad Safeda', planted in different spacing

\begin{tabular}{cccccc}
\hline Treatments & $6 \times 2 \mathrm{~m}$ & $6 \times 3 \mathrm{~m}$ & $6 \times 4 \mathrm{~m}$ & $6 \times 5 \mathrm{~m}$ & Mean \\
\hline PBZ 500 & 5.45 & 4.90 & 4.68 & 5.25 & 5.07 \\
PBZ 1000 & 5.60 & 5.26 & 6.05 & 5.50 & 5.60 \\
Ethephon 500 & 5.88 & 5.62 & 4.59 & 5.15 & 5.31 \\
Ethephon 1000 & 6.19 & 5.49 & 4.71 & 5.40 & 5.45 \\
Control & 6.46 & 6.25 & 5.83 & 5.98 & 6.13 \\
Mean & 5.92 & 5.53 & 5.17 & 5.46 & 5.48 \\
\hline
\end{tabular}

CD (p-0.05)-Spacing (A): 0.98 Treatments (B): $0.11 \mathrm{~A} \times \mathrm{B}: 0.21$ significant reduction in length of shoot production following PBZ application in 'Alphonso' mango. The mean maximum spread in E-W direction was measured in plants at $6 \times 2 \mathrm{~m}$ spacing, while in N-S direction, it was noted maximum in plants at widest $(6 \times 5 \mathrm{~m})$ spacing. Plant at $6 \times 4 \mathrm{~m}$ spacing in E-W and $6 \times 3 \mathrm{~m}$ in N-S direction exhibited least spread. Ravishankar et al. (2008) also recorded higher E-W tree spread in guava plants with maximum inter-row space. Lower tree spread (E-W) in high density plants may be due to the limitation of interplant space, resulting more E-W growth at the expense of N-S growth. Mitra and Bose (1990) also observed greater tree spread at low planting density. Singh and Bal (2002) reported maximum tree spread in wider spacing $(6 \times 6 \mathrm{~m})$ in East-West direction. Singh (2006) also observed the similar changes in tree spread with growth retardants.

The tree spread (E-W) among treated plants was recorded highest at $6 \times 2 \mathrm{~m}$ spacing at $1000 \mathrm{ppm}$ ethephon application and minimum in the treatment of $6 \times 4 \mathrm{~m}$ at 500 ppm ethephon. Similarly, in N-S direction, untreated plant gave maximum tree spread and ethephon and PBZ treated plants at $6 \times 3 \mathrm{~m}$ spacing provided plants with reduced tree spread in N-S direction.

Tab. 5. Effect of growth regulators on tree spread (N-S) (m) of guava 'Allahabad Safeda', planted in different spacing

\begin{tabular}{cccccc}
\hline Treatments & $6 \times 2 \mathrm{~m}$ & $6 \times 3 \mathrm{~m}$ & $6 \times 4 \mathrm{~m}$ & $6 \times 5 \mathrm{~m}$ & Mean \\
\hline PBZ 500 & 3.00 & 3.97 & 4.74 & 5.05 & 4.19 \\
PBZ 1000 & 3.00 & 3.94 & 4.60 & 4.66 & 4.05 \\
Ethephon 500 & 3.00 & 3.92 & 3.98 & 4.38 & 3.82 \\
Ethephon 1000 & 3.00 & 3.97 & 4.30 & 4.93 & 4.05 \\
Control & 3.00 & 4.05 & 4.72 & 5.31 & 4.27 \\
Mean & 3.00 & 3.97 & 4.47 & 4.87 & 4.08 \\
\hline
\end{tabular}

CD (p-0.05)-Spacing (A): 0.048 Treatments (B): $0.54 \mathrm{~A} \times \mathrm{B}: 0.10$

\section{Tree canopy volume}

The tree canopy affected significantly with growth retardants and plant spacing. Although all treatments restricted the tree volume but more than $25 \%$ restriction was observed in PBZ $500 \mathrm{ppm}$ application as compared to control (Tab. 6). Singh (2006) also observed the similar changes in tree canopy with growth retardants.

Similarly, the plant canopy was found increased with increase in plant spacing. Trees at $6 \times 5 \mathrm{~m}$ produce maximum tree canopy. Generally, the decreased tree canopy of guava in closer spacing may be due to shading effect and overlapping of branches thereby leading to reduced availability of photosynthates as well as nutrients from the soil (Arora et al., 1983). Mitra and Bose (1990) also observed the greater spread of crown at low planting density in guava. Kumar and Singh (2000) showed decreasing trend of tree canopy volume with the increasing tree density.

Similarly, the interactions between spacing and PGR treatments with regard to tree canopy volume were also 
Tab. 6. Effect of growth regulators on canopy volume $\left(\mathrm{m}^{3}\right)$ of guava 'Allahabad Safeda', planted in different spacing

\begin{tabular}{cccccc}
\hline Treatments & $6 \times 2 \mathrm{~m}$ & $6 \times 3 \mathrm{~m}$ & $6 \times 4 \mathrm{~m}$ & $6 \times 5 \mathrm{~m}$ & Mean \\
\hline PBZ 500 & 36.72 & 38.11 & 37.75 & 44.09 & 39.17 \\
PBZ 1000 & 38.33 & 41.82 & 50.17 & 44.42 & 43.69 \\
Ethephon 500 & 41.80 & 45.28 & 36.76 & 40.46 & 41.05 \\
Ethephon 1000 & 40.85 & 40.76 & 38.24 & 48.80 & 42.16 \\
Control & 46.79 & 54.87 & 55.23 & 58.35 & 53.81 \\
Mean & 40.90 & 44.17 & 43.61 & 47.22 & 43.98 \\
\hline
\end{tabular}

$\mathrm{CD}(\mathrm{p}-0.05)$ Spacing (A): 1.23 Treatments (B): $1.37 \mathrm{~A} \times \mathrm{B}: 2.75$

found significantly different. Minimum tree canopy volume was noted in $6 \times 2 \mathrm{~m}$ spacing with PBZ $500 \mathrm{ppm}$ treatment.

\section{Conclusions}

From the above study it can be concluded that the canopy management by restricting the growth with PBZ and ethephon coupled with increasing the plant population per unit area may be exploited for increasing the productivity level of guava orchards. Present investigation revealed that PBZ and ethephon had great impact on vegetative growth of guava plants. PBZ at $500 \mathrm{ppm}$ having highest growth retardation effect may be further investigated for managing the guava tree canopies under high density planting, taking the fruit quality and economic aspects into consideration.

\section{References}

Arora, R. K., R. Yamdagni and B. S. Chundawat (1983). Effect of different spacings on growth, yield and quality on kinnowA Mandarin hybrid. Prog. Hort. 15:17-23.

Bal, J. S. and G. S. Dhaliwal (2003). High density planting studies in guava. Haryana J.Hort. Sci. 32:19-22.

Gaur, G. S., R. K. Yadav, D. Gangwar and P. N. Katiyar ( 2005). Standerdization of planting density and crop regulation treatments in guava (Psidium guajava L.) 'Sardar'. Abstract $1^{\text {st }}$ International Guava symposium, CISH, Lucknow.

Kumar, R. and H. P. Singh (2000). Effect of planting systems cum densities on growth, fruit size and yield of guava 'Allahabad Sufeda' under rainfed conditions. Ann. Agric. Res. 21:152-153.
Mitra, S. K. and T. K. Bose (1990). Guava, p.286-301. In: BoseT. K. and S. K. Mitra Eds. The Fruits of India-Tropical and Sub-tropical, Naya Prakash, Calcutta.

Mohammed, S., L. A. Wilson and N. Prendergast (1984). Guava meadow orchard: Effect of ultra high density planting and growth regulator on growth, flowering and fruiting. Trop. Agric. 61:297-301.

Reddy, Y. T. N. and R. M. Kurian (2008). Commulative and residual effects of paclobutrazol on growth, yield and fruit quality of 'Alphonso' mango. J. Hort. Sci. 3:119-122.

Ravishankar, H., T. N. Shivananda and A. G. Purohit (2008). Effect of planting density on growth parameters and fruit yield in guava ( Psidium guajava L.) 'Allahabad Safeda' cultivated in mid humid conditions of Coorg. J. Hortl. Sci. 3:123-126.

Roose, M. L., D. A. Cole, D. Atkin and R. S. Kuper (1986). Yield and tree size of four citrus cultivars on 21 rootstocks in California. J. Amer. Soc. Hort. Sci. 114:135-140.

Sidhu, P. J. S., S. K. Kalra, G. S. Dhaliwal and R. Singh (1992). Effect of different spacings on vegetative growth and nutrient level in the leaves of guava 'Allahabad Sufeda'. Punjab Hort. J. 32:55-59.

Singh, G. and Y. R. Chanana (2005). Influence of pruning intensity and pruning frequency on vegetative and reproductive attributes in guava 'L-49' Abstract: $1^{\text {st }}$ International Guava Symposium, CISH, Lucknow.

Singh, G., A. K. Singh and D. Mishra (2007). High density planting in guava. Acta Horticulturae 735:2235-2241.

Singh, H. J. and J. S. Bal (2006). Effect of pruning and growth regulators on physico- chemical characters of guava during rainy season planted at different spacing. Int. J. Agric. Sci. 2(2):533-537.

Singh, J. and J. S. Bal (2002). Effect of planting density on tree growth, fruit yield and quality of 'Sardar' guava (Psidium guajava L.). J. Res. Punjab. Agric. Univ. 39:56-62.

Singh, R. (2006). High density planting studies in Sardar guava (Psidium guajava L.) M.Sc Thesis, PAU, Ludhiana.

Yadav, E. D., N. R. Gaikwad and A. V. Patil (1981). The relation between tree growth, chlorophyll content and plant density of Sardar guava (Psidium guajava L.). National Symposium on Tropical and Subtropical Fruit Crops, Bangalore. 